\title{
Potassium in Relation to Yield, Quality and Economics of Brinjal - Cabbage Cropping System
}

\author{
T. Chaitanya*, G. Padmaja and P. Chandrasekhar Rao \\ Department of Soil Science and Agricultural Chemistry, College of Agriculture, \\ Rajendranagar, Professor Jayashankar Telangana State Agricultural University, \\ Hyderabad - 500030, India \\ *Corresponding author
}

\section{A B S T R A C T}

\begin{tabular}{|l|}
\hline Ke y w o r d s \\
$\begin{array}{l}\text { Potassium, Brinjal - } \\
\text { cabbage cropping } \\
\text { system, X is K- } \\
\text { fixing capacity of } \\
\text { soil }\end{array}$ \\
\hline Article Info \\
\hline $\begin{array}{l}\text { Accepted: } \\
\text { 07 March } 2019 \\
\text { Available Online: } \\
\text { 10 April } 2019\end{array}$ \\
\hline
\end{tabular}

\section{Introduction}

Potassium is an essential nutrient for crops and plays an important role in several physiological processes in plant. It is the fourth most abundant element, constituting about 2.5 per cent of the lithosphere. However, actual soil concentrations of this element vary widely, ranging from 0.04 to 3 per cent. Potassium content in soils depends on the type of parent material and degree of mineral weathering (Sparks and Huang, 1985).

Generally the crop response to $\mathrm{K}$ application is expected, where the soils are low in available potassium. But, there are reports, where crop response to $\mathrm{K}$ fertilization is positive even in soils high in $\mathrm{K}$ status. This suggests that factors other than the level of available $\mathrm{K}$ in surface soil can influence the growth and $\mathrm{K}$ availability to plants (Bidari and Hebsur, 2011).

With intensive cultivation of high yielding varieties and hybrids under alternate wetting and drying conditions, process of $\mathrm{K}$-fixation and release is taking place from secondary clay minerals, which is also governing the $\mathrm{K}$ availability to crops. The potassium fixing capacity of soils depends on several factors viz., type of clay minerals, soil texture, soil 
type, moisture content etc. Potassium fixing capacity of soils has to be considered to give K-recommendations to crops apart from available K status of soils (Srinivasa Rao and Khera, 1995).

India is a leading vegetable producer and ranks second in the world next to China. In Telangana brinjal is cultivated in 15,110 hectares with a production and productivity of 3.02 lakh Metric tonnes and 20 Metric tonnes per hectare, respectively. Cabbage is cultivated in 5,630 hectares with a production of 0.84 lakh Metric tonnes and productivity of 15 Metric tonnes per hectare (National Horticultural Board, 2014). Vegetable crops respond to $\mathrm{K}$ nutrition and play an important role in increasing the yield and quality of produce. However, it was found that there was imbalanced fertilizer application with or without K-fertilization to vegetable crops.

To meet the urban demand for vegetables, farmers are growing vegetables in surrounding districts of Hyderabad which includes Ranga Reddy and Mahaboobnagar. Brinjal-cabbage cropping system is one of the predominant systems in these districts. Keeping in view of the importance of $\mathrm{K}$ to vegetable crops, the study of potassium in relation to yield, quality and economics of Brinjal - Cabbage cropping system was carried out.

\section{Materials and Methods}

Field experiment was conducted at College Farm, College of Agriculture, PJTSAU, Rajendranagar, Hyderabad during kharif and rabi (2013-2014) in a sandy loam soil (Alfisol) with brinjal - cabbage cropping system in Randomized Block Design with seven treatments replicated thrice. In the field experiment of brinjal - cabbage cropping system, potassium was applied based on the $\mathrm{K}$ fixing capacity $\left(27 \quad \mathrm{~kg} \quad \mathrm{~K}_{2} \mathrm{O} \quad \mathrm{ha}^{-1}\right)$ and recommended dose of potassium to brinjal $\left(60 \mathrm{~kg} \mathrm{~K}_{2} \mathrm{O} \mathrm{ha}{ }^{-1}\right)$. For deciding the levels of potassium the values for $0, \mathrm{RDK}, 0.5 \mathrm{X}, \mathrm{X}$, 1.5X, 2X, 2.5X kg K $2 \mathrm{O} \mathrm{ha}^{-1}$ ( $\mathrm{X}$ is the $\mathrm{K}$-fixing capacity of soil) were calculated and 0,60 , 73.5, 87, 100.5, 114, $127.5 \mathrm{~kg} \mathrm{~K} \mathrm{~K}_{2} \mathrm{O} \mathrm{ha}^{-1}$, respectively. After harvest of brinjal, an uniform dose of potassium was applied to cabbage (100 $\left.\mathrm{kg} \quad \mathrm{K}_{2} \mathrm{O} \quad \mathrm{ha}^{-1}\right)$ for all the treatments $\left(\mathrm{T}_{2}\right.$ to $\left.\mathrm{T}_{7}\right)$ except control $\left(\mathrm{T}_{1}\right)$ and the residual effect of potassium applied to brinjal was seen. The initial soil sample was collected (0-15 cm depth) prior to the layout of the experiment and analyzed for physical and chemical properties following standard analytical methods. During different stages of crops soil samples were collected and analyzed for physical and chemical properties following standard analytical methods

\section{Available potassium}

The available potassium was determined by $\mathrm{NN} \mathrm{NH}_{4} \mathrm{OAc}$ with 1:5 soil extract, after 5 minutes shaking as described by Hanway and Heidal (1952).

\section{Potassium fixing capacity of soils}

The potassium fixing capacity of soils was determined by following the wet fixation method outlined by Ghosh et al., (1983). Well processed soil $(5 \mathrm{~g})$ was taken in each of the nine conical flasks and potassium through $\mathrm{KCl}$ solution was added to give the concentrations of $0,25,50,100,150,200$, 250, 300 and $500 \mu \mathrm{g} 5 \mathrm{~g}^{-1}$ soil in such a manner that the final soil: solution ratio was adjusted to 1: 2 . The contents in the flasks were incubated for 72 hours at room temperature taking all necessary precautions to prevent evaporation. After incubation, 25 $\mathrm{ml}$ of $\mathrm{NN} \mathrm{NH}_{4} \mathrm{OAc}$ solution was added to all the conical flasks. The contents were shaken for 5 minutes and $\mathrm{K}$ in the filtrate was estimated using flame photometer. Potassium 
fixing capacity was computed from the amounts of $\mathrm{K}$ added and extracted at different levels.

Salient soil characteristics of the experimental site

The initial soil sample collected from experimental field was analyzed for physical and chemical properties. The soil was sandy loam in texture, slightly alkaline $(7.9 \mathrm{pH})$ in reaction, non saline $\left(0.286 \mathrm{dS} \mathrm{m}^{-1}\right)$, high in organic carbon $\left(8 \mathrm{~g} \mathrm{~kg}^{-1}\right)$ and low in available nitrogen (175.6 kg ha-1), low in available phosphorus (20.5 $\left.\mathrm{kg} \mathrm{P}_{2} \mathrm{O}_{5} \mathrm{ha}^{-1}\right)$ and high in available potassium $\left(419.3 \mathrm{~kg} \mathrm{~K}_{2} \mathrm{O} \mathrm{ha}{ }^{-1}\right)$. The soil has CEC of $15.9 \mathrm{cmol}\left(\mathrm{p}^{+}\right) \mathrm{kg}^{-1}$. The Kfixing capacity of the experimental soil found to be $27 \mathrm{~kg} \mathrm{~K}_{2} \mathrm{O} \mathrm{ha}^{-1}$.

\section{Results and Discussion}

\section{Fruit yield}

The total fruit yield of the brinjal and the fresh curd yield of the cabbage recorded at different pickings were presented in table 1 and shown in the figure 1 and 2 . The yield of brinjal varied from 6.71 to $11.21 \mathrm{t} \mathrm{ha}^{-1}$ with a mean of $8.66 \mathrm{t} \mathrm{ha}^{-1}$. The lowest and highest yields were recorded at $\mathrm{T}_{1}$ (control) and $\mathrm{T}_{7}$, respectively. However, the fruit yield recorded at $\mathrm{T}_{7}\left(11.21 \mathrm{t} \mathrm{ha}^{-1}\right)$ was significantly superior over all other treatments. With increase in potassium levels the fruit yield was increased.

The results revealed that, application of 127.5 $\mathrm{kg} \mathrm{K}_{2} \mathrm{O} \mathrm{ha}^{-1}$ has resulted in highest fresh fruit yield $\left(11.2 \mathrm{t} \mathrm{ha}^{-1}\right)$. The per cent increase in yield found to be 13 from $\mathrm{T}_{6}$ to $\mathrm{T}_{7}$ and 6 from $\mathrm{T}_{5}$ to $_{6}$. This showed that there was significant increases in brinjal yield at 127.5 $\mathrm{kg} \mathrm{K} \mathrm{O}_{2} \mathrm{O} \mathrm{ha}^{-1}$ compared to application of 114
$\left(\mathrm{T}_{6}\right)$ and $100.5\left(\mathrm{~T}_{5}\right) \mathrm{kg} \mathrm{K}_{2} \mathrm{O} \mathrm{ha} \mathrm{ha}^{-1}$, indicating the response of brinjal to higher levels of $\mathrm{K}$ application. The results are in conformity with Thakre et al., (2005) and Akhtar et al., 2010.

The yield of cabbage varied from 19 to $31.5 \mathrm{t}$ $\mathrm{ha}^{-1}$ with a mean of $27 \mathrm{t} \mathrm{ha}^{-1}$. The lowest and highest yields were recorded at $\mathrm{T}_{1}$ (control, No $\mathrm{K}$ ) and $\mathrm{T}_{7}$ (Rec. dose of $\mathrm{K}_{2} \mathrm{O}+2.5 \mathrm{X} \mathrm{kg}$ $\mathrm{K}_{2} \mathrm{O} \quad \mathrm{ha}^{-1}$ i.e., $127.5 \quad \mathrm{~kg} \quad \mathrm{~K}_{2} \mathrm{O} \quad \mathrm{ha}^{-1}$ ), respectively. However, the curd yield recorded at $\mathrm{T}_{7}\left(31.5 \mathrm{t} \mathrm{ha}^{-1}\right)$ was on par with $\mathrm{T}_{4}, \mathrm{~T}_{5}$ and $\mathrm{T}_{6}$ and significantly superior over all other treatments. Cole season crops such as cabbage and cauliflower show response to $\mathrm{K}$ application.

Since potassium promotes winter hardiness in cabbage, the highest yield was recorded in treatment $T_{7}$ where the readily available form of potassium was high. Response of cole season crops to high levels of potassium even upto $150 \mathrm{~kg} \mathrm{~K}_{2} \mathrm{O} \mathrm{ha}{ }^{-1}$ was reported by Tiwari and Sulewski, (2004) and Singh et al., (2010).

As a blanket recommended dose of potassium $100 \mathrm{~kg} \mathrm{~K}_{2} \mathrm{O} \mathrm{\textrm {ha } ^ { - 1 }}$ was applied to all the treatments, there was no significant variation in curd yield from $T_{7}$ to $T_{5}$ though highest values were recorded. But the curd yield differed significantly when compared to $\mathrm{T}_{4}$, $\mathrm{T}_{3}, \mathrm{~T}_{2}$ and $\mathrm{T}_{1}$. This was due to availability of more potassium to cabbage after harvest of brinjal from the treatments where high levels of $\mathrm{K}$ was applied i.e., $\mathrm{T}_{7}\left(127.5 \mathrm{~kg} \mathrm{~K}_{2} \mathrm{O}\right.$ ha $^{-1}$ ) and $\mathrm{T}_{6}\left(114 \mathrm{~kg} \mathrm{~K}_{2} \mathrm{O}\right.$ ha $\left.^{-1}\right)$.

\section{Quality parameters}

Fresh brinjal fruits and cabbage curds at harvest were analyzed for quality parameter viz., ascorbic acid content. The data pertaining to ascorbic acid content (mg $100 \mathrm{~g}^{-1}$ ) was given in table 1 . 
Table.1

\begin{tabular}{|c|c|c|}
\hline & Soil character & Method of analysis \\
\hline I) & Physical properties & \\
\hline a) & Particle size analysis & $\begin{array}{l}\text { Bouyoucos hydrometer method } \\
\text { (Piper, 1966) }\end{array}$ \\
\hline II) & Physico-chemical properties & \\
\hline a) & $\begin{array}{l}\text { Soil reaction }(\mathrm{pH}) \\
(1: 2.5 \text { soil: water suspension })\end{array}$ & $\begin{array}{l}\text { Glass electrode pH meter, Model } \\
\text { DI-707 (Jackson, 1973) }\end{array}$ \\
\hline b) & $\begin{array}{l}\text { Electrical conductivity } \\
(1: 2.5 \text { soil: water extract })\end{array}$ & $\begin{array}{l}\text { Conductivity meter, DI-909 } \\
\text { (Jackson, 1973) }\end{array}$ \\
\hline III) & Chemical properties & \\
\hline 1) & Organic carbon $\left(\mathrm{g} \mathrm{kg}^{-1}\right)$ & $\begin{array}{l}\text { Wet digestion method (Walkley } \\
\text { and Black, 1934) }\end{array}$ \\
\hline 2) & $\begin{array}{l}\text { Cation exchange capacity } \\
\left(\mathrm{cmol}(\mathrm{p}+) \mathrm{kg}^{-1}\right)\end{array}$ & $\begin{array}{l}\text { Bower } \text { et al., } 1952 \text { as described by } \\
\text { Richards et al., (1954) }\end{array}$ \\
\hline 3) & Available nutrients & \\
\hline a) & Nitrogen $\left(\mathrm{kg} \mathrm{ha}^{-1}\right)$ & $\begin{array}{l}\text { Alkaline permanganate method } \\
\text { (Subbiah and Asija, 1956) }\end{array}$ \\
\hline b) & Phosphorus $\left(\mathrm{kg} \mathrm{P}_{2} \mathrm{O}_{5}\right.$ ha $\left.^{-1}\right)$ & Olsen's method (Olsen et al., 1954) \\
\hline
\end{tabular}

Table.2 Effect of levels of potassium on yield $\left(\mathrm{t} \mathrm{ha}^{-1}\right)$ and quality (ascorbic acid content) of brinjal and cabbage

\begin{tabular}{|c|c|c|c|c|}
\hline \multirow[t]{2}{*}{ Treatments } & \multicolumn{2}{|c|}{ Brinjal } & \multicolumn{2}{|c|}{ Cabbage } \\
\hline & $\begin{array}{l}\text { Yield } \\
\text { (t/ha) }\end{array}$ & $\begin{array}{l}\text { Ascorbic } \\
\text { acid } \\
\left(\mathbf{m g ~} 100 \mathrm{~g}^{-1}\right)\end{array}$ & $\begin{array}{l}\text { Yield } \\
\text { (t/ha) }\end{array}$ & $\begin{array}{c}\text { Ascorbic } \\
\text { acid } \\
(\mathbf{m g ~ 1 0 0 g} \\
1 \text { ) }\end{array}$ \\
\hline $\mathrm{T}_{1}$ Control (No K) & 6.7 & 2.90 & 19.0 & 14.5 \\
\hline $\begin{array}{l}\mathrm{T}_{2} \text { Recommended dose of } \mathrm{K}_{2} \mathrm{O}(\mathrm{kg} \\
\left.\mathrm{ha}^{-1}\right)\end{array}$ & 7.3 & 3.38 & 24.9 & 16.4 \\
\hline $\begin{array}{l}\mathrm{T}_{3} \text { Rec. dose of } \mathrm{K}_{2} \mathrm{O}+0.5 \times \mathrm{kg} \mathrm{K}_{2} \mathrm{O} \\
\text { ha }^{-1}\end{array}$ & 8.1 & 3.87 & 26.1 & 17.9 \\
\hline $\mathrm{T}_{4}$ Rec. dose of $\mathrm{K}_{2} \mathrm{O}+\mathrm{X} \mathrm{kg} \mathrm{K} \mathrm{O}_{2} \mathrm{ha}^{-1}$ & 8.5 & 4.35 & 28.1 & 18.9 \\
\hline $\begin{array}{l}\mathrm{T}_{5} \text { Rec. dose of } \mathrm{K}_{2} \mathrm{O}+1.5 \mathrm{X} \mathrm{kg} \mathrm{K} \mathrm{K}_{2} \mathrm{O} \\
\mathrm{ha}^{-1}\end{array}$ & 9.1 & 4.83 & 28.9 & 19.3 \\
\hline $\begin{array}{l}\mathrm{T}_{6} \text { Rec. dose of } \mathrm{K}_{2} \mathrm{O}+2 \mathrm{X} \mathrm{kg} \mathrm{K} \mathrm{K}_{2} \mathrm{O} \\
\mathrm{ha}^{-1}\end{array}$ & 9.7 & 5.32 & 30.3 & 19.8 \\
\hline $\begin{array}{l}\mathrm{T}_{7} \text { Rec. dose of } \mathrm{K}_{2} \mathrm{O}+2.5 \mathrm{X} \mathrm{kg} \mathrm{K} \mathrm{K}_{2} \mathrm{O} \\
\mathrm{ha}^{-1}\end{array}$ & 11.2 & 5.80 & 31.5 & 20.3 \\
\hline CD (0.05) & 1.18 & 1.01 & 4.87 & 0.90 \\
\hline $\mathrm{SE}(\mathrm{m}) \pm$ & 0.38 & 0.33 & 1.56 & 0.29 \\
\hline
\end{tabular}


Table.3 Effect of different levels of potassium on benefit - cost ratio of brinjal

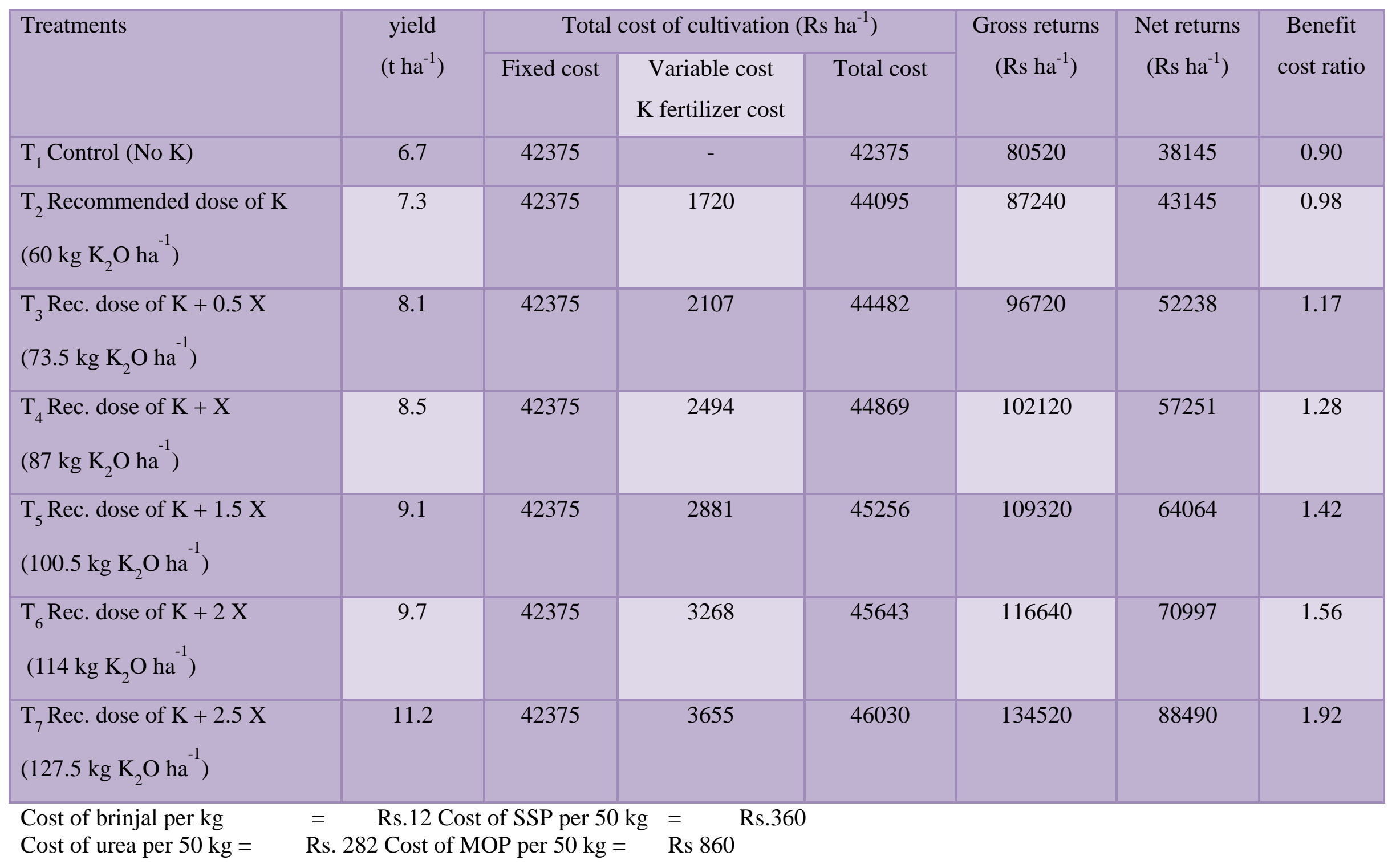


Table.4 Effect different levels of potassium on benefit - cost ratio of cabbage

\begin{tabular}{|c|c|c|c|c|c|c|c|}
\hline \multirow[t]{2}{*}{ Treatments } & \multirow{2}{*}{$\begin{array}{l}\text { yield } \\
\left(\mathrm{t} \mathrm{ha}^{-1}\right)\end{array}$} & \multicolumn{3}{|c|}{ Total cost of cultivation $\left(\mathrm{Rs} \mathrm{ha}^{-1}\right)$} & \multirow{2}{*}{$\begin{array}{l}\text { Gross returns } \\
\qquad\left(\mathrm{Rs} \mathrm{ha}^{-1}\right)\end{array}$} & \multirow{2}{*}{$\begin{array}{l}\text { Net returns } \\
\left(\mathrm{Rs} \mathrm{ha}^{-1}\right)\end{array}$} & \multirow{2}{*}{$\begin{array}{l}\text { Benefit } \\
\text { cost ratic }\end{array}$} \\
\hline & & Fixed cost & $\begin{array}{c}\text { Variable cost } \\
\text { K fertilizer cost }\end{array}$ & Total cost & & & \\
\hline $\mathrm{T}_{1}$ Control (No K) & 19.0 & 38806 & - & 38806 & 76000 & 37194 & 0.96 \\
\hline $\begin{array}{l}\mathrm{T}_{2} \text { Recommended dose of } \mathrm{K} \\
\left(60 \mathrm{~kg} \mathrm{~K}_{2} \mathrm{O} \mathrm{ha}{ }^{-1}\right)\end{array}$ & 24.9 & 38806 & 2867 & 41673 & 99640 & 57967 & 1.39 \\
\hline $\begin{array}{l}\mathrm{T}_{3} \text { Rec. dose of } \mathrm{K}+0.5 \mathrm{X} \\
\left(73.5 \mathrm{~kg} \mathrm{~K}_{2} \mathrm{O} \mathrm{ha}{ }^{-1}\right)\end{array}$ & 26.1 & 38806 & 2867 & 41673 & 104280 & 62607 & 1.50 \\
\hline $\begin{array}{l}\mathrm{T}_{4} \text { Rec. dose of } \mathrm{K}+\mathrm{X} \\
\left(87 \mathrm{~kg} \mathrm{~K}_{2} \mathrm{O} \mathrm{ha}\right.\end{array}$ & 28.1 & 38806 & 2867 & 41673 & 112280 & 70607 & 1.69 \\
\hline $\begin{array}{l}\mathrm{T}_{5} \text { Rec. dose of } \mathrm{K}+1.5 \mathrm{X} \\
\left(100.5 \mathrm{~kg} \mathrm{~K}_{2} \mathrm{O} \mathrm{ha}{ }^{-1}\right)\end{array}$ & 28.9 & 38806 & 2867 & 41673 & 115680 & 74007 & 1.78 \\
\hline $\begin{array}{l}\mathrm{T}_{6} \text { Rec. dose of } \mathrm{K}+2 \mathrm{X} \\
\left(114 \mathrm{~kg} \mathrm{~K}_{2} \mathrm{O} \mathrm{ha}^{-1}\right)\end{array}$ & 30.3 & 38806 & 2867 & 41673 & 121200 & 79527 & 1.91 \\
\hline $\begin{array}{l}\mathrm{T}_{7} \text { Rec. dose of } \mathrm{K}+2.5 \mathrm{X} \\
\left(127.5 \mathrm{~kg} \mathrm{~K}_{2} \mathrm{O} \mathrm{ha}{ }^{-1}\right)\end{array}$ & 31.5 & 38806 & 2867 & 41673 & 126120 & 84447 & 2.03 \\
\hline $\begin{array}{l}\text { Cost of cabbage per kg } \\
\text { Cost of urea per } 50 \mathrm{~kg}=\end{array}$ & $\begin{array}{c}\text { Rs.5 } \\
82 \text { Cost }\end{array}$ & $\begin{array}{l}\text { of SSP per } \\
\text { IOP per } 50\end{array}$ & Rs $860=$ & Rs.360 & & & \\
\hline
\end{tabular}


Table.5 Effect different levels of potassium on benefit - cost ratio of brinjal - cabbage cropping system

\begin{tabular}{|c|c|c|c|}
\hline & $\begin{array}{c}\text { Total cost of cultivation } \\
\left(\mathrm{Rs} \mathrm{ha}^{-1}\right)\end{array}$ & $\begin{array}{l}\text { Net returns } \\
\left(\text { Rs ha }^{-1}\right)\end{array}$ & BC ratio \\
\hline $\mathrm{T}_{1}$ Control (No K) & 81181 & 61919 & 0.76 \\
\hline $\begin{array}{l}\mathrm{T}_{2} \text { Recommended dose of } \mathrm{K} \\
\left(60 \mathrm{~kg} \mathrm{~K}_{2} \mathrm{O} \mathrm{ha}^{-1}\right)\end{array}$ & 85768 & 86572 & 1.01 \\
\hline $\begin{array}{l}T_{3} \text { Rec. dose of } \mathrm{K}+0.5 \mathrm{X} \\
\left(73.5 \mathrm{~kg} \mathrm{~K}_{2} \mathrm{O} \mathrm{ha}^{-1}\right)\end{array}$ & 86155 & 98725 & 1.15 \\
\hline $\begin{array}{l}T_{4} \text { Rec. dose of } \mathrm{K}+\mathrm{X} \\
\left(87 \mathrm{~kg} \mathrm{~K}_{2} \mathrm{O} \mathrm{ha}^{-1}\right)\end{array}$ & 86542 & 110838 & 1.28 \\
\hline $\begin{array}{l}T_{5} \text { Rec. dose of } \mathrm{K}+1.5 \mathrm{X} \\
\left(100.5 \mathrm{~kg} \mathrm{~K}_{2} \mathrm{O} \mathrm{ha}{ }^{-1}\right)\end{array}$ & 86929 & 119851 & 1.38 \\
\hline $\begin{array}{l}T_{6} \text { Rec. dose of } \mathrm{K}+2 \mathrm{X} \\
\left(114 \mathrm{~kg} \mathrm{~K} \mathrm{O} \mathrm{ha}^{-1}\right)\end{array}$ & 87316 & 131084 & 1.50 \\
\hline $\begin{array}{l}\mathrm{T}_{7} \text { Rec. dose of } \mathrm{K}+2.5 \mathrm{X} \\
\left(127.5 \mathrm{~kg} \mathrm{~K}_{2} \mathrm{O} \mathrm{ha}^{-1}\right)\end{array}$ & 87703 & 150517 & 1.72 \\
\hline
\end{tabular}

Fig.1 Effect of different levels of potassium on fruit yield of brinjal

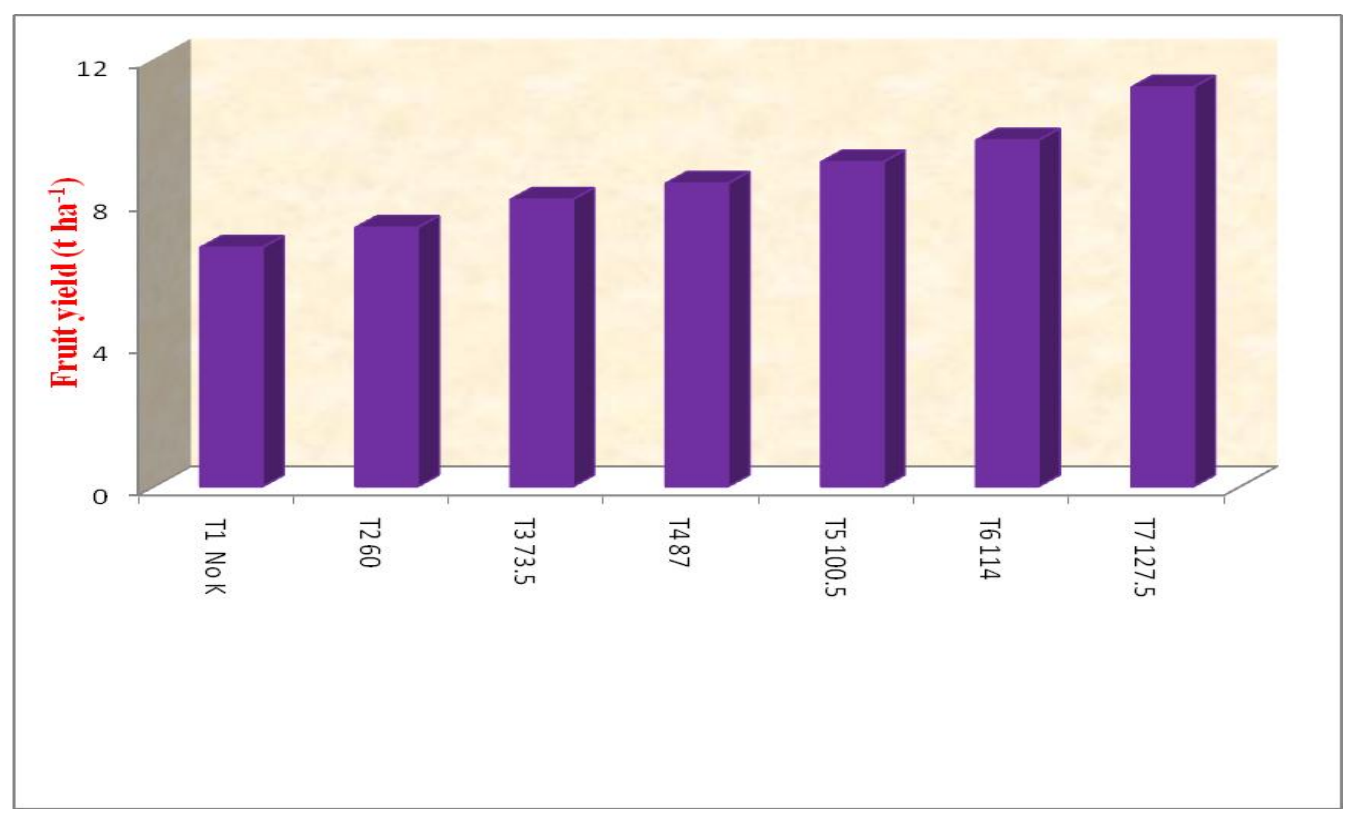


Fig.2 Effect of different levels of potassium on curd yield of cabbage

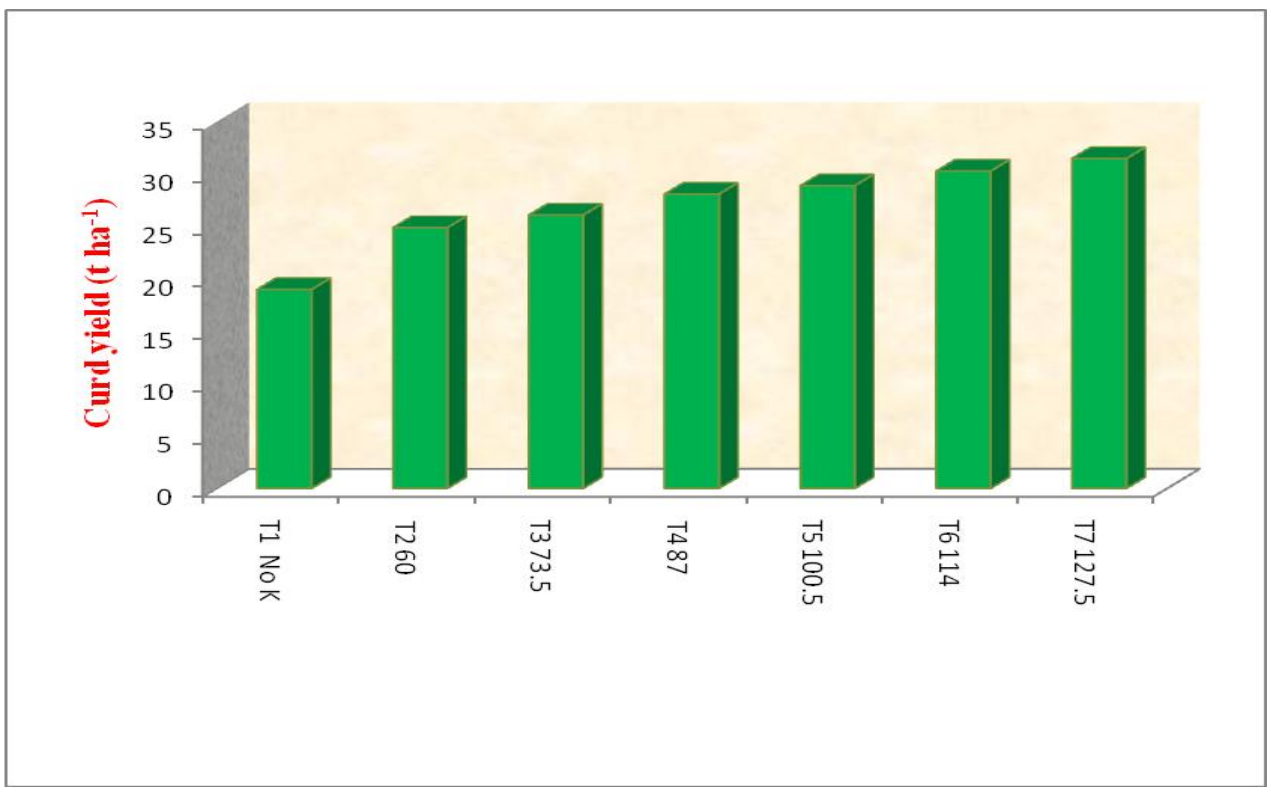

\section{Ascorbic acid}

In brinjal fruits ascorbic acid content varied from 2.9 to 5.8 with a mean value of $4.4 \mathrm{mg}$ $100 \mathrm{~g}^{-1}$ of fruit. The highest value $5.8 \mathrm{mg}$ $100 \mathrm{~g}^{-1}$ of fruit was recorded in $\mathrm{T}_{7}((127.5 \mathrm{~kg}$ $\mathrm{K}_{2} \mathrm{O}$ ha ${ }^{-1}$ ) but was on par with $\mathrm{T}_{6}$ and $\mathrm{T}_{5}$ and was significantly different from all other

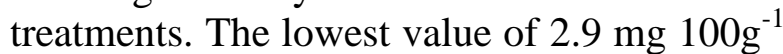
of fruit was recorded in $\mathrm{T}_{1}$ (control, No K). The results are in conformity with Thakre et al., (2005). In cabbage ascorbic acid content varied from 14.5 to $20.3 \mathrm{mg} 100 \mathrm{~g}^{-1}$ of curd. The highest value of $20.3 \mathrm{mg} 100 \mathrm{~g}^{-1}$ of curd was recorded in $\mathrm{T}_{7}\left(127.5 \mathrm{~kg} \mathrm{~K}_{2} \mathrm{O} \mathrm{ha}^{-1}\right)$. However, the content recorded at $\mathrm{T}_{7}$ was on par with $T_{6}$ and was significantly different from all other treatments. Similar reports by Majumdar et al., (2000) and Ananthi et al., (2004).

Available $\mathrm{K}$ has significant positive correlation with quality attribute ascorbic acid in brinjal $(\mathrm{r}=0.944 * *)$ and cabbage $(\mathrm{r}=$ 0.984**). Bidari and Hebsur (2011) also showed that $\mathrm{K}$ content in vegetables bears significant positive relationship with quality attributes. In addition to its effects on plant growth and thereby yield quantity, potassium has been described as the quality element for crop production (Deshpande et al., 2013).

\section{Benefit cost ratio}

Results pertaining to the economics of brinjal are presented in table 2. Among the different treatment combinations, the lowest and highest yields were recorded at $\mathrm{T}_{1}$ (control, No $\mathrm{K}$ ) and $\mathrm{T}_{7}$ (Rec. dose of $\mathrm{K}_{2} \mathrm{O}+2.5 \mathrm{X} \mathrm{kg}$ $\mathrm{K}_{2} \mathrm{O} \quad \mathrm{ha}^{-1}$ i.e., $127.5 \quad \mathrm{~kg} \quad \mathrm{~K}_{2} \mathrm{O} \quad \mathrm{ha}^{-1}$ ), respectively. However, the fruit yield recorded at $\mathrm{T}_{7}\left(11.21 \mathrm{t} \mathrm{ha}^{-1}\right)$ was significantly superior over all other treatments. Considering the cost of inorganic fertilizers, the net returns obtained from $\mathrm{T}_{7}$ found to be Rs 88490 per hectare followed by $\mathrm{T}_{6}$ (Rs 70997). Whereas, considering the total cost of cultivation and net returns, the $\mathrm{B}: \mathrm{C}$ ratio was highest in treatment $\mathrm{T}_{7}$ (Rec. dose of $\mathrm{K}_{2} \mathrm{O}+$ $2.5 \mathrm{X} \mathrm{kg} \mathrm{K}_{2} \mathrm{O}^{-1}{ }^{-1}$ i.e., $\left.127.5 \mathrm{~kg} \mathrm{~K}_{2} \mathrm{O} \mathrm{ha}^{-1}\right)$ i.e., 1.92 , followed by $\mathrm{T}_{6}(1.56)$.

Results pertaining to the economics of cabbage are presented in table 3. Among the 
different treatment combinations, the lowest and highest yields were recorded at $\mathrm{T}_{1}$ (control, No K) and $\mathrm{T}_{7}$ (Rec. dose of $\mathrm{K}_{2} \mathrm{O}+$ $2.5 \mathrm{X} \mathrm{kg} \mathrm{K}_{2} \mathrm{O} \mathrm{ha}^{-1}$ i.e., $127.5 \mathrm{~kg} \mathrm{~K}_{2} \mathrm{O} \mathrm{ha}{ }^{-1}$ ), respectively. However, the curd yield recorded at $\mathrm{T}_{7}\left(31.5 \mathrm{t} \mathrm{ha}^{-1}\right)$ was on par with $\mathrm{T}_{6}, \mathrm{~T}_{5}$ and $\mathrm{T}_{4}$ and significantly superior over all other treatments. The net returns obtained from cabbage found to be Rs 84447 at $\mathrm{T}_{7}$ followed by $\mathrm{T}_{6}$ (Rs 79527). The $\mathrm{B}$ : $\mathrm{C}$ ratio at $\mathrm{T}_{7}$ was 2.03 which were higher than all other treatments. It was also found that with same amount of total cost of cultivation (Rs 41,673) incurred on treatments $T_{2}$ to $T_{7}$, the $B$ : $C$ ratio and net returns were high in $\mathrm{T}_{7}$. This might be due to availability of more potassium to cabbage ( $>100 \mathrm{~kg} \mathrm{~K}_{2} \mathrm{O} \mathrm{ha}{ }^{-1}$ ) after harvest of brinjal, which might have increased the curd yield of cabbage and in turn net returns.

The benefit cost ratio of brinjal - cabbage cropping system as a whole was also calculated and found highest net returns of Rs 150517 with a benefit cost ratio of 1.72 at $\mathrm{T}_{7}$ followed by $\mathrm{T}_{6}$ (Table 4 ).

It was also found that there was response to K-fertilizers even in high $\mathrm{K}$ soil $(419.3 \mathrm{~kg}$ $\mathrm{ha}^{-1}$ ) by vegetable like brinjal and cabbage which are heavy feeders of potassium. To meet the $\mathrm{K}$ demand of these crops when grown on light textured soils, there is a need to apply high levels of potassium more than the recommended dose after taking into account the K-fixing capacity of soils and other parameters (Table 5).

Conclusion from the present investigation was found that application of $127 \mathrm{~kg} \mathrm{~K}_{2} \mathrm{O} \mathrm{ha}^{-1}\left(\mathrm{~T}_{7}\right)$ not only sustained the K-fertility status, but also gave higher yield, net returns with higher $\mathrm{B}: \mathrm{C}$ ratio of brinjal - cabbage cropping system. Quality was also improved with increase in potassium levels. There is a need to consider the K-fixing capacity of soils for giving potassium recommendations to crops.

\section{References}

Akhtar, M. E., Khan, M. Z., Rashid, M. T., Ahsan, Z And Ahmad, S. 2010. Effect of potash application on yield and quality of tomato (Lycopersicon esculentum Mill.). Pakistan Journal of Botony 42(3): 1695-1702.

Ananthi, S., Veeraragavathatham, D and Srinivasan, K. 2004. Influence of sources and levels of potassium on quality attributes of chilli (Capsicum annuum L.). South Indian Horticulture. 52 (1-6): 152-157.

Bidari, B. I. and Hebsur, N. S. 2011. Potassium in relation to yield and quality of selected vegetable crops Karnataka Journal Agricultural Sciences. 24 (1): 55-59.

Bower, C.A., Reitemeir, R.F and Fireman, M. 1952. Exchangeable cation analysis of saline and alkaline soils. Soil Science. 73:251-261.

Deshpande, A. N., Dhage, A.R and Bhalerro, V.P. 2013. Potassium nutrition for improving yield and quality of onion. Indian Journal of Fertilizers. 14-21.

Ghosh, S.K., Bajaj, J.C., Hassan, R and Singh, D.1983. Potassium fixing capacity of soil. In soil and water testing methods, a laboratory manual, soil testing laboratory, IARI, New Delhi. 26 - 29.

Hanway, J and Heidal, H.C. 1952. Soil analysis methods as used in Iowa State College Soil Testing laboratory. Iowa State College Agricultural bulletin No. 57: 1-31.

Jackson, M.L. 1973. Soil chemical analysis. Prentice hall of India Private Limited, New Delhi. India.

Majumdar, S.P., Meena, R.L and Baghel, G.D.S. 2000. Effect of levels of compaction and potassium on yield and quality of tomato and chilli crops grown on highly permeable soils. 
Journal of the Indian Society of Soil Science. 48 (2): 215-220.

National Horticultural Board. 2014. http://www.indiastat.com.

Olsen, S.R., Cole, C.V., Watanabe, F.S and Dean, L.A. 1954. Estimation of available phosphorus in soil by extracting with sodium bicarbonate. USDA Circ. 939, Washington. In Soil Chemical Analysis (ed. M. L. Jackson) Prentice Hall of Indian Private Limited, New Delhi.

Piper, C.S. 1966. Soil and Plant Analysis. Hans Publishers, Bombay. Singh, J.S., Sandeep Singh and Vinay Singh. 2010. Soil potassium fractions and response of Cauliflower and Onion to Potassium. Journal of the Indian Society of Soil Science. 58(4): 3843887.

Sparks, D.L and P.M. Huang. 1985. Physical chemistry of soil potassium. In Potassium in agriculture. (Eds RD
Munson et al.,) 201-276.

Srinivasa Rao, Ch and Khera, M.S., 1995, Potassium fixation characteristics and fertilizer potassium requirements of illitic alluvial soils by two steps alternate methods. Journal of the Indian Society of Soil Science. 43: 86191.

Thakre, C.M., Badole, W.P., Tiwari, T.K and Sarode, P.B. 2005, Effect of different levels of sulphur, phosphorus and potassium on yield and quality of brinjal. Journal of Maharashtra Agricultural University. 30 (3): 352353.

Tiwari, K.N and Sulewski, G.2004. Potassium Deficiency Symptoms in Vegetable Crops. Better Crops. 88 (4) : 36-38.

Walkley, A and Black, C.A. 1934. Estimation of organic carbon by chromic acid titration method. Soil Science. 37: 2938.

\section{How to cite this article:}

Chaitanya, T., G. Padmaja and Chandrasekhar Rao, P. 2019. Potassium in Relation to Yield, Quality and Economics of Brinjal - Cabbage Cropping System. Int.J.Curr.Microbiol.App.Sci. 8(04): 687-696. doi: https://doi.org/10.20546/ijcmas.2019.804.074 